\title{
Reconstruction of Wages System for Balinese Dancer in Tourism Industry
}

\author{
I Wayan Gde Wiryawan \\ Faculty of Law \\ University of Mahasaraswati \\ Denpasar, Indonesia \\ gdewiryawan1976@gmail.com
}

\begin{abstract}
In practice, the wages earned by Balinese dancers are very far from those specified in the rules. This study is made to examine the legal protection on wages for Balinese dancers in the tourism industry and to explore the efforts that can be made to establish the Balinese dancers' wages system. This study is designed with a qualitative approach comprising critical research that targets not only to explore the meaning of the ethics but also create the meaning of the ethics. Qualitative data were collected in the form of Balinese dancers' problems, government regulations and policies, Balinese dancing management techniques by dance studio, obstacles and constraints in protecting, social problems, economic condition of Balinese dancers, reward and punishment system to Balinese dancers involved in tourism industry, customary law in the protection of the citizens, the advantages and disadvantages of the Bali Customary Law-based dancers. Results show that the protection of wages for Balinese dancers in the tourism industry is not optimal. The efforts that can be made to establish a Balinese dancer wages system involved in the tourism industry is through legal substance, structure, and culture.
\end{abstract}

Keywords-Balinese dancer; wage; tourism industry

\section{INTRODUCTION}

Bali has a strong tourism attraction in the world, both for domestic and foreign tourists. One of the cultures becoming a tourist attraction is the arts. Art is very popular in Bali so it seems to dominate the entire life of Balinese people in Bali. As the basis of such a function, art is a focus of Balinese culture [1]. Some research results and surveys explain that most tourists visiting Bali are motivated by the uniqueness of Balinese art and culture. Balinese art and culture are recognized to have different nuances, and contain high artistic values. One form of art and culture of the Balinese people is the art of dance. The art of dance is a performing art that is usually played or performed by many people through body movements, by using the distinctive costumes or clothing, as a whole unity [2]

The art of dance is one of the components as a tourist attraction to visit Bali, the art of dance is much growing and developing in the area which is a tourist area such as: Badung regency, Gianyar regency and Denpasar city [3]. Along with the development of tourism industry in Bali, the arts are classified as entertainment (balih-balihan) especially the art of dance which has developed quite rapidly, both gestures and various modes of clothing.

The rapid flow of commercialization in the field of culture, especially the art of Balinese dance, is not in line with the welfare felt by the dancers. The absence of protection economically, socially, and technically becomes a current phenomenon. Empirical facts show that the low wages, ranging from Rp. 20,000 to Rp. 50,000 for one show, the transport of dancers with pick-up cars that are very far from safety aspects, inadequate performance facilities and supports, such as improper place for dressing, stage location in front of tourists who are eating, and the other problems are the phenomena which cannot be denied. In fact, behind the success of commercializing dance as a commodity of tourism, the existence and development of dance art, especially in Bali is inseparable from the loyalty and high dedication of the dancers.

Wages are an important aspect that determines the welfare of Balinese dancers. Unfortunately, the wages received by dancers are still very small if it is compared to the other artists such as modern singers and dancers. In fact, in addition to have the economic goals, Balinese dance performances also carry the mission of cultural preservation. Meanwhile, the government has not shown optimal efforts to regulate wages for Balinese dancers working in the tourism industry. This research will discuss the protection of wages for Balinese dancers in the tourism industry and the efforts that can be made to establish the Balinese dancers' wage system.

\section{METHOD}

This study is designed with a qualitative approach comprising critical research that targets not only to explore the meaning of the ethics but also create the meaning of the ethics. Qualitative data were collected in the form of Balinese dancers' problems, government regulations and policies, Balinese dancing management techniques by dance studio, obstacles and constraints in protecting, social problems, economic condition of Balinese dancers, reward and punishment system to Balinese dancers involved in tourism industry, customary law in the protection of the citizens, the advantages and disadvantages of the Bali Customary Law-based dancers. 


\section{RESULT AND DISCUSSION}

\section{A. The Protection of Wages for Balinese Dancers in Tourism Industry}

Balinese dance is one of the cultural heritage of sustainable art in Indonesia, which has distinctive characteristics, with different movement rhythms according to the type of the dance. By following the rhythm of gamelan accompaniment, so that the dancer must understand well about the dance movements. The relationship of dance and religious ceremony in Bali is very close, in which most every religious event in Bali includes dances. Therefore, in terms of Balinese, there are three functions of dance such are (1) Wali Dance, this type of dance is most sacred by Hindu society and only performed on certain moments of religious ceremonies at the temple which have similar roles and movements; (2) Bebali dance, performed during a religious ceremony at the temple, which serves as a companion and contains different roles on each dancer; (3) Bali-balihan dance, dance performances that have the meaning of entertaining, so it becomes art / dance entertainment for the community.

So far, the guarantee of Balinese art and culture in the form of Bali Governor's Regulation No. 14 of 20125 on the Type, Quality and Place of Local Art Performances for Tourists, refers to the type of local art that can be demonstrated for tourists, the quality of local art that can be displayed for tourists, registration of sekaa/sanggar/organization of art, as well as permit performances where the staging area and other facilities. The Governor's Regulation does not specifically regulate the protective construction of Balinese dancers.

The development of tourism in Bali with the concept of Culture Tourism is very rapidly develop. It has made tourism as an industry that becomes the spearhead in the development of Bali in general and Gianyar in particular. Recognizing this has led to efforts to harness culture as a supporter of tourism. One of the dominant cultures used to support tourism is Balinese Dance. The existence of pakraman 'indigenous villages' in Bali which becomes one of the institutions becoming the basis of the development of Balinese Dance has not been optimal in regulating the emergence of the phenomena of Balinese Dance as one of the supporting culture of the tourism industry which systematically led to a shift in the value of the existence of Balinese dancers into the utilization of Balinese dancers excessive in supporting the tourism industry. This makes the problem of weaker protection of Balinese dancers.

The lack of government's attention to the fate of artists, especially dancers, causes the welfare and protection of the rights that should be accepted by dancers exceeded. It was not in line when former Bali governor Ida Bagus Mantra initiated and hosted Bali's first art party (Bali Art Festival) in 1979. The Balinese arts party at the beginning of its performances was regarded as the enlightening brightener of the art world, as well as the broadest expression arena for artists, including Balinese dancer. Nevertheless, at present the dignity of artists, especially Balinese dancers as the guardians of the national identity, seems not to feel the sanctification or protection of the sincere love of the government and institutions of customary institutions as a shelter.

The paradigm developed by Balinese dancers generally states that dancing activity is more emphasized on the term ngayah (doing the job without getting paid / paid) which in its development the term ngayah is used also when dancers dance all kinds of Balinese dance on every occasion including in the realm of the tourism industry without considering the consequences especially for the dancer itself. According to the dancer, the dancing activity is a dedication, and they say, "As long as I can dance, I'm happy". In fact, starting from the training process until it is said to be ready to dance, requires a lot of money and energy. The mindset is actually exploited by the parties concerned about dance performances for the purpose of commercialization. So far the discussion on the protection of new arts to the work art of dance only, while the setting of minimum standards of wages for Balinese dancers working in the tourism sector does not yet exist.

\section{B. Efforts to Establish the Balinese Dancers' Wage System in Tourism Industry}

Theoretically, the state has a legal obligation to protect the people and administer social justice. In this case, the state has duties and obligations i.e.:

- Maintain the public interest, which is specific to the common interests of the citizens, which cannot be carried out by the citizens themselves.

- Maintain the public interest in the sense of the common interest of the citizens, which cannot be carried out by the citizens themselves.

- Maintain the common interest of individual citizens who are not entirely capable of their own citizens, in the form of assistance from the state. There are times when the state maintains the interests of individuals.

- The State protects the entire nation of Indonesia, including ethnic groups, families and individual citizens.

- The state is obliged to promote the welfare and the environment for the dignity of life for every tribe, every class of citizens, every family, every individual citizen. The maintenance is carried out either by the state or by individuals themselves not with state aid or with state aid [4].

Conception of the welfare state or a modern legal state or a material legal state characterized by the following:

- In the preferred welfare state, the state is guaranteed the socio-economic rights of the people.

- Considerations of efficiency and management take precedence over political-oriented power sharing, so that the role of the executive is greater than the legislature.

- Property rights are not absolute. 
- The state not only maintains order and security or just the night watchman (nachtwakerstaat), but the state participates in social and economic endeavors.

- Administrative law rules govern more socioeconomically and impose certain obligations on the part of citizens.

- The role of Public Law is inclined to urge the Private Law, as a consequence of the increasing role of the state.

- More of a material legal state that prioritizes social justice is also material [5].

In implementing the duty to promote welfare, the state has the authority to rebuild the wage system of the workers, especially for Balinese dancers working in the tourism sector. The assurance of the welfare of the community is the responsibility of the government, while on the other hand it becomes the basic right of the community. Article 22 of the Universal Declaration of Human Rights states that

Everyone, as a member of society, has the right to social security and is entitled to realization, through national effort and international co-operation and in accordance with the organization and resources of each State, of the economic, social and cultural rights indispensable for his dignity and the free development of his personality.

Article 23 The Universal Declaration of Human Rights specifically regulates on matters in the field of employment. As stated in the article:

\section{Article 23}

- Everyone has the right to work, to free choice of employment, to just and favourable conditions of work and to protection against unemployment.

- Everyone, without any discrimination, has the right to equal pay for equal work.

- Everyone who works has the right to just and favourable remuneration ensuring for himself and his family an existence worthy of human dignity, and supplemented, if necessary, by other means of social protection.

- Everyone has the right to form and to join trade unions for the protection of his interests.

Traditional dance art is part of local wisdom that must be maintained and preserved. Constitutionally, the recognition of local wisdom has been regulated in the 1945 Constitution, particularly in article 18B paragraph (2), that "the State recognizes and respects the unity of indigenous and tribal peoples as long as they are alive and in accordance with the development of society and principles of Unitary State of the Republic of Indonesia as governed by law". Recognition of the existence of local wisdom by the Constitution of the Republic of Indonesia became the basis for the inclusion of local wisdom in the substance of various laws and regulations in Indonesia either implicitly or explicitly.
In protecting the local wisdom, art workers should be protected in order to be able to always maintain the cultural values that have been inherited by the ancestors. Related to the social welfare of the dancers, Article 28H Paragraph (3) of the Constitution of 1945 states "Everyone has the right to social security which enables his complete development as a dignified human being." Subsequently Article 34 Paragraph (2) of the Constitution 1945 which states "The State develops a social security system for all people and empowers a weak and incapable society in accordance with human dignity."

Tourism is a multi-dimensional and multi-disciplinary tourism-related activity that emerges as a manifestation of the needs of every person and country as well as the interaction between tourists and the local community, fellow travelers, the Government, local government, and employers. Tourism is organized based on the principle of benefit, kinship, justice and equality, balance, independence, sustainability, participatory, sustainable, democratic, equality and unity. The problem of tourism in Indonesia is regulated in Law Number 10 Year 2009 on Tourism. Article 4 of Act Number 10 Year 2009 on Tourism formulated that Tourism aims to:

- Increase economic growth;

- Improve the welfare of the people;

- Eradicate poverty;

- Tackle the unemployment;

- Conserve nature, environment, and resources;

- Promote culture;

- Lift the image of the nation;

- Foster the love of the homeland;

- Strengthen the identity and unity of the nation; and

- Cultivate friendship among nations.

In accordance with the objective of tourism that is to improve the welfare of the people as set in Article $4 \mathrm{~b}$ Law Number 10 Year 2009 on Tourism, it is necessary efforts to set minimum standards of wages for Balinese dancers. In 2015, the Governor issued a regulation namely Governor of Bali Regulation No. 14 of 2015 on the type, quality and place of local art performances for tourists. The regulation is expected to serve the needs of the community and the people who work in the field of tourism performances.

The Governor's Regulation is a policy issued by the Provincial Government of Bali in exercising executive power. In connection with government policy, David Easton declared the government policy as the authority to allocate values for society as a whole [6]. Thomas R. Dye states that what is meant by public policy is as the government's choice to determine the steps to do or not to do [6]. This Governor Regulation is also expected to be able to make changes in society such as the creation of order in the field of licensing for art organizations to perform in hotels, restaurants or artistic stages aimed at commercialization. 
The Government's efforts in guaranteeing wages for Balinese dancers can be seen in Article 6 of Bali's Governor Regulation No. 14 of 2015 on the Type, Quality and Place of Regional Art for Visitors:

In carrying out its activities, the owner/manager of sekaa/sanggar/organization of regional arts must:

- Observe and preserve religious values, cultural customs and morals and public order;

- Use appropriate regional arts clothing, tailored to the needs of staging( for the dancers and gamelan players);

- Use gamelan accompaniment for the benefit of seminars, lectures and the others;

- Be responsible in fulfilling obligations to artists administered under an agreed agreement;

- Signing of contract between art service user and artist/art organization to be implemented by both parties directly without going through intermediary services;

- Provide a decent wage;

- Do performances according to the duration of each type of performance;

- Take care of departure and return artists performing local art performances;

- Use the appropriate transportation, except to transport gamelan/other performing facilities is permitted to use open transportation;

- Organize regional art performances;

- Have provision of social security to art organizations such as insurance;

- Submit reports on local art performances to the Governor through the Provincial Cultural Office of Bali once a month.

The provisions of Article $6 \mathrm{f}$ of the Governor of Bali Regulation No. 14 of 2015 concerning the Type, Quality and Place of Regional Art for Tourists only determine the right wages, whereas the definition of "worthy effort" does not exist. The Bali Provincial Government does not specify the nominal wage that is suitable for Balinese dancers. This is in contrast to the provision of wages in the District, Provincial and City Minimum Wages that have been determined in number. The absence of a definition of a decent wage for a dancer causes entrepreneurs have a chance to pay at a low price. This condition is due to subjectivity in the understanding of "decent wages."

In the context of labor protection, wages become a very important component. Better labor protection is aimed at improving wages, working conditions and relationships, occupational safety and health and other social security protection of employment as written by Zaenal Asikin covers aspects such as:

- Legal protection, where applicable laws and regulations in the field of employment which require or impose an employer acting in accordance with the legislation and actually implemented by all parties concerned.

- Economic protection, i.e. protection related to the efforts to provide workers with an adequate income to meet their daily needs for them and their family.

- Social protection, i.e. protection related to community enterprises whose purpose is to enable the worker to embrace and develop his life as a human being and as a member of society.

- Technical protection, i.e. safeguards relating to efforts to keep workers from the hazards of accidents caused or related to occupational safety and health [6].

The efforts that can be made to protect the wages for Balinese dancers can be viewed from the side of legal substance, structure, and draft. The substance of the law also includes the rule of law. The rule of law that can be applied is the rule of law that qualifies law enforcement. The law enforcement consists of:

- Social validity or factual validity; this is due to the effectiveness of the rule of law.

- The Implementation of Yuridik; that a rule of law is established in accordance with the rules of law, applicable procedure, and by the competent authority.

- Moral Implementation; in this case the issue is the quality or legitimacy of the law [7].

Artists are not protected by the Governor of Bali Regulation No. 14 of 2015 on the type, quality and place of local art performances for tourists. The provision actually provides an obligation for the artists and even impose sanctions on the artist. This condition can be seen in Article 11 which states as follows:

1) Any Sekaa/Sanggar/organization of arts not meeting the provisions referred to in Article 3, Article 4, Article 5, Article 6. Article 7, and Article 8, shall be liable to administrative sanctions.

2) The administrative sanctions as referred to in paragraph (1) shall be in the form of:

- Written reprimands;

- Restrictions on business activities; and

- Temporary freezing of business activities.

The legal structure mentioned in the Bali Governor's Regulation Number 14 Year 2015 Concerning the Type, Quality and Place of Regional Art Tourists does not have the authority to protect dancers. Article 9 mentions (1) Guidance and supervision on the type, quality and place of local art performances conducted by the Governor; (2) In conducting the guidance and supervision as meant in paragraph (1) a Coordination Team established by the Governor shall be established; (3) The Regional Development and Supervision Team shall be conducted by the Head of Bali Provincial Cultural Office. 
The lack of wages received by the dancers cannot be separated from the legal culture. The legal culture that exists in society is strongly influenced by religion, one's position in society, one's interests and even career factors [8]. Muladi sees legal culture as an abstract system of law which is the climate of social force which determines how law is used, avoided or abused. Further said without this legal culture, the legal system would be helpless, like a dead fish in a basket, not as a fish swimming in the sea. Thus, legal culture should be a central part of legal development [9].

The show is often positioned as a complement to the show, usually dinner at the hotel / restaurant. Artists are provided with a simple facility and are often not properly introduced. How can deep appreciation occur when the audience's attention should be shared between eating and watching a performance? In places of tourism tour guide or driver who leads tourists get a commission of $25-50 \%$ of the price of admission. Similarly, art brokers (intermediaries between artists and buyers) take a high percentage of the price offered so that the wages received by artists are minimal [10].

\section{CONCLUSION}

The protection of wages for Balinese dancers in the tourism industry is not yet optimal. The dancers are only paid Rp. 20.000,00- Rp. 50.000,00 for each stage. The low wages of Balinese dancers are caused by the fact that this art is only considered as a complement in the tourism industry, although Balinese dance is a tourist attraction in Bali. The efforts that can be made to establish a Balinese dancer wages system involved in the tourism industry is to make regulations on the minimum wages that must be given to dancers who work in the tourism industry. Monitoring of wages for Balinese dancers also needs to be done by the Provincial Cultural Office of Bali. The Bali Provincial Government also needs to impose sanctions on brokers who take most of the wages from Balinese dancers. Government and art workers must work together to raise the level and dignity of Balinese dance.

\section{ACKNOWLEDGEMENT}

The author would like to thank all the parties who have helped and contributed in the writing of this article, both those who contribute in the form of funding and critical ideas. Hopefully this paper can be useful theoretically and practically for the addition and development of knowledge, especially in the field of legal science.

\section{REFERENCES}

[1] Dinas Pariwisata Provinsi Bali (Bali Government Tourism Office), Informasi Objek dan Daya Tarik Wisata di Bali, Denpasar. 2014.

[2] F. Novrisal, "Perlindungan Karya Cipta Seni Tari (Studi Terhadap Konsep dan Upaya Perlindungan Hak Cipta Seni Tari di Kalangan Seniman Tari Yogyakarta)". Program Magister Ilmu Hukum Program Pasca Sarjana Universitas Diponegoro, 2009.

[3] Ruastiti, N. M., Seni Pertunjukan Bali dalam Kemasan Pariwisata, Bali Mangsi Press, Denpasar. 2005.

[4] Kaelan, Filsafat Pancasila, Paradigma, Yogyakarta. 2002.

[5] M. Iver, Negara Modern, terjemahan Moertono, Aksara Baru, Jakarta. 1984.

[6] S. Lubis, Kebijakan Publik, Mandar Maju, Bandung. 2007.

[7] A. Sidharta, Meuwissen tentang Pengembangan Hukum, Ilmu Hukum, Teori Hukum, dan Filsafat Hukum, PT. Refika Aditama, Bandung. 2007.

[8] H. Tahir, Proses Hukum yang Adil Dalam Sistem Peradilan Pidana di Indonesia, Laksbang, Yogyakarta. 2010.

[9] Muladi, Hak Asasi Manusia, Politik dan Sistem Peradilan Pidana, Badan Penerbit Universitas Diponegoro, Semarang. 1997.

[10] I. G. R. P. Tisna, "Sekilas Tentang Dinamika Seni Pertunjukan Tradisional Bali dalam Konteks Pariwisata Budaya", available from: URL: http://www.budpar.go.id/budpar/asp/detil.asp?c=5\&id=1031 